\title{
Effect of Foreign Direct Investment on China Economic Growth: A Granger Causality Approach.
}

\author{
Agya, Atabani Adi ${ }^{1}$, Wunuji, Emmanuel Adimani ${ }^{2}$ \\ ${ }^{1}$ Department of Economics, Federal University, Wukari-Nigeria \\ ${ }^{2}$ Department of Economics, Federal University, Wukari-Nigeria
}

\begin{abstract}
The paper focuses on the causal effect of Foreign Direct Investment (FDI) on Economic growth of China and study period spanned from 1995 to 2010. Times series data drawn from the primary, secondary and tertiary sectors of the economy were used for the analysis. Granger causality statistical method was used in testing causal effect among the variables; we used E-view statistical software (version7). The KwiatkowskiPhilips-Schmidt-Shin (KPSS) unit root tests for stationary indicates that the variables are stationary at level. The Granger causality test indicates that, utilized FDI do not cause economic growth in primary industry, FDI in secondary industry cause economic growth and Economic growth cause FDI inflows in secondary industry, while economics growth cause FDI flow to tertiary industry of the economy. We recommend as follows; (1) Countries intending to benefit from FDI should carry out necessary and sufficient research before rolling out the policy and do so strategically as no all industry has casual effect on economic growth (2) The authority of host nation should divide foreign investment market to encouraged, restricted and prohibited industries. (3) Host nation should provide necessary incentive to FDI flowing to secondary and tertiary industry of the economy where necessary.
\end{abstract}

Key words: Foreign Direct Investment, Economic Growth in China, Granger Causality Approach.

\section{Introduction}

In the last three decade Foreign Direct Investment (hereinafter FDI) remained the potent force (Engine) that propel growth of Chinese economy by complimenting the domestic saving and investment which fall short of what is required for the economy transformation, technology transfer, spillover effect, superior management know-how, employment opportunity and acquisition of new skills from foreign organization has greatly increase income to saving and domestic investment and productivity in the economy, these trend has help transform the economy since the reformed and opening up policy in 1979, China's has attracted substantial amount of FDI flows to its economy and these has impacted positively to the growth of Chinese economy. Whalley and Xian (2006) conclude that, the contribution of FDI to Chinese growth is quite substantial on the order of 3-4 percentage points per year,

It is on this premise Chinese Government (Central, Provincials and Locals level) offered different degree of incentive to encouraged FDI flows to it economy. It's widely believed that the type of FDI and its structural composition matter at least as much for economic growth effects as does the overall volume of inward FDI. Agrawal and Shahani (2005) reckon that it is the quality of FDI that matters for a country rather than its quantity. FDI is often supposed to be of higher quality if it is export oriented, transfers foreign technologies to the host country, and induces economic spillovers benefiting local enterprises and workers (Enderwick, 2005). All the more surprisingly, the structure and type of FDI are hardly considered in previous empirical studies on the FDI-growth links in China.

This paper exploits the casual effect of FDI inflows across sector (Primary, Secondary and Tertiary) on China's economic growth, spanning from 1995-2010 covering the period immediately after the declaration of Socialist market economy by Chinese Communist party in 1992 and the accession to World Trade Organization (WTO) in 2001.

The article is structured as follows: The next section present literatures review, section three highlights the methodology employed in the study and the sources of data. Empirical results and analysis will be done in fourth section while the discussion is completed by conclusions and policy recommendation in section five.

\section{Empirical Review}

The impact of foreign direct investment on economic growth in china has been well research, however little has been done to explain its effect on sectoral level and the direction of causation in the economy. This paper will survey the literature on sectoral impact of FDI in China. 
Tam, Vu and Ilan (2006) show that, effect is not equally distributed across economic sectors. FDI only has a consistently positive effect on growth in the manufacturing sector; its effect on other sectors is usually statistically insignificant, in some cases even negative. Chang and Zhang (1995) examine the growth effect of FDI in China, use data for selected cities and provinces during the 1979-1991 periods. They regressed the log of GNP on FDI and found a positive growth effect. John and Xian (2006) assumed that, the marginal revenue per FDI dollar is equalized across aggregate sectors of the economy (agriculture, manufacturing, and services). Nadia (2006) used a sample of 60 countries analyzed sector (Manufacturing and service) specific effect of FDI on growth by dividing the countries into income level, and found a positive effect on growth in manufacturing and negative effect in service sector. Zhang (2001) uses data from 1984 to 1998 for 28 provinces and finds that, generally, FDI has positive effect on economic growth in China through its interaction with human capital. Jiang and Masaru (2010) used latest data from 30 industries in Jiangxi Province People Republic of China; the impact of FDI has a bias on industries. It concentrated in only several sectors. Both the interconnection and the induced capacity are high in those sectors. Wen (2003) shows that, FDI only has positive effects on economic growth in China's coastal provinces, which have more open policies toward foreign investors than the inland provinces by separating the Chinese economy into an FDI and a non-FDI sector. Edward and Erika (2001) used D-G\&H to analyzed growth effect of FDI in Chinese provinces and found that total factor productivity growth in coastal province is strong while weak evidence of growth effect exists in Northwestern province. Whalley and Xian (2006) conclude that, the contribution of FDI to Chinese growth is quite substantial (on the order of 3-4 percentage points per year). James and Kam (2006) state that, FDI strongly promote income growth at national and provincial levels.

Nicole and Sandra (2006) analyzed the growth performance of FDI on Chinese cities with data of 1990-2002 using GMM and found a positive effect of growth from FDI in these cities. Huang (2003) uses the augmented Solow-Swan model of Mankiw, Romer and Weil (1992) data from provinces of China over the reform period 1978-2003, finds that FDI has a positive and statistically significant impact on economic growth as theory predicts and the augmented Solow-Swan model provides an excellent fit of the data. Lo (2004) examined the role of FDI in Economic development of China with broader literature and found the followings: First, that FDI tends to promote the improvement in allocative efficiency, while having a negative impact on productive efficiency. Second, insofar as FDI does promote overall productivity growth, this tends to be a matter of cumulative causation rather than one of single-direction causation. Third, in the context of a comparative analysis of two distinctive regional models, that the economic impact of FDI tends to be more favourable in the inward-looking, capital-deepening pattern.

In an empirical research, Wanda and Harm (2003) suggests that FDI has raised total factors productivity growth in china by 2.5 percentage points per year during the 1990s. Again, this effect was found to be strongest in provinces that have received most FDI. Thus, in sum, FDI has contributed nearly 2 percentage point of potential gross domestic product growth for China. Fung, Hitomi and Sarah (2002) state that: "There is a positive correlation between investments by Foreign invested enterprises and GDP growth at both national level and provincial level and increasing FDI inflow has been an important part of China's growth". (Chandana and Peter, 2006: p29), FDI is not a panacea for economic growth and employment creation (Christopher 2007:p26). Samuel (2009) observed that, FDI contributes to economic development of host country in two main ways; augmentation of domestic capital and enhancement of efficiency through the transfer of new technology, marketing and managerial skills, innovation and best practices and secondly; FDI has both benefits and costs and its impact is determined by the country specific conditions such as policy environment, ability to diversify, level of absorption capacity, targeting of FDI and linkages between FDI and domestic investment. FDI is the main engine of growth in Guandong Province and that the growth effect is divergent in this region (Lo 2005,p53),

All these works has been able to show positive effect of FDI in different region across china but none of these papers analyze the effect of FDI by distinguishing direct investment by industry and the direction of causal effect, hence the need for this work to bring to fold a new insight into importance of FDI on economic growth of host nation.

\subsection{Model Specification \\ 3.1.1 Granger causality}

III. Methodology

Granger causality tests are conducted to determine whether the current and lagged values of one variable affect another. One implication of Granger representation theorem is that if two variables, say $X_{t}$ and $Y_{t}$ are co-integrated and each is individually $\mathrm{I}(1)$, then either $X_{t}$ must Granger-cause $Y_{t}$ or $Y_{t}$ must Granger-cause $\mathrm{X}_{\mathrm{t}}$. This causality of co-integrated variables is captured in Vector Error Correction Model (VECM). The long and short-run parameters are separated. In the present study linear combinations of non-stationary variables are 
not found stationary, that is, the variables are not co-integrated. In absence of co-integration the unrestricted VAR in first difference is estimated, (Omoke and Ugwuanyi, 2010).

Granger causality is normally tested in the context of linear regression models. This can be stated as follow:

$$
\begin{aligned}
& \mathrm{Y}_{(\mathrm{t})}=\quad \sum_{j=1}^{p} \mathrm{~A}_{11 j} \mathrm{Y}_{(\mathrm{t}) 11}(\mathrm{t}-\mathrm{j}) \quad+\sum_{j=1}^{p} \mathrm{~A}_{12 j} \mathrm{FDI}_{\mathrm{tpri}}(\mathrm{t}-\mathrm{j}) \quad+\sum_{j=1}^{p} \mathrm{~A}_{13 j} \operatorname{FDI}_{\mathrm{tsec}}(\mathrm{t}-\mathrm{j})+\sum_{j=1}^{p} \mathrm{~A}_{14 j} \mathrm{FDIt}_{\mathrm{tter}}(\mathrm{t}-\mathrm{j})+\mathrm{E}_{1} \\
& \mathrm{FDI}_{\mathrm{tpri}}=\quad \sum_{j=1}^{p} \mathrm{~A}_{21 j} \mathrm{Y}_{(\mathrm{t}) 21}(\mathrm{t}-\mathrm{j}) \quad+\sum_{j=1}^{p} \mathrm{~A}_{22 j} \mathrm{FDI}_{\mathrm{tpri}}(\mathrm{t}-\mathrm{j})+\sum_{j=1}^{p} \mathrm{~A}_{23 j} \operatorname{FDI}_{\mathrm{tsec}}(\mathrm{t}-\mathrm{j})+\sum_{j=1}^{p} \mathrm{~A}_{24 j} \operatorname{FDIt}_{\mathrm{tter}}(\mathrm{t}-\mathrm{j})+\mathrm{E}_{1}(\mathrm{t})
\end{aligned}
$$

$\mathrm{FDI}_{\mathrm{tsec}}=$

)

$$
\sum_{j=1}^{p} \mathrm{~A}_{31 j} \mathrm{Y}_{(\mathrm{t}) 31}(\mathrm{t}-\mathrm{j})+\sum_{j=1}^{p} \mathrm{~A}_{32 j} \mathrm{FDI}_{\mathrm{tpri}}(\mathrm{t}-\mathrm{j})+\sum_{j=1}^{p} \mathrm{~A}_{33 j} \operatorname{FDI}_{\mathrm{tsec}}(\mathrm{t}-\mathrm{j})+\sum_{j=1}^{p} \mathrm{~A}_{34 j} \operatorname{FDIt}_{\mathrm{tter}}(\mathrm{t}-\mathrm{j})+\mathrm{E}_{1}(\mathrm{t})
$$

$\mathrm{FDI}_{\mathrm{tter}}=\quad \sum_{j=1}^{p} \mathrm{~A}_{41 j} \mathrm{Y}_{(\mathrm{t}) 41}(\mathrm{t}-\mathrm{j})$

$$
+\sum_{j=1}^{p} \mathrm{~A}_{42 j} \mathrm{FDI}_{\mathrm{tpri}}(\mathrm{t}-\mathrm{j})+\sum_{j=1}^{p} \mathrm{~A}_{43 j} \operatorname{FDI}_{\mathrm{tsec}}(\mathrm{t}-\mathrm{j})+\sum_{j=1}^{p} \mathrm{~A}_{44 j} \operatorname{FDIt}_{\mathrm{tter}}(\mathrm{t}-\mathrm{j})+\mathrm{E}_{1}(\mathrm{t})
$$

)$\ldots \ldots \ldots \ldots \ldots . . . .(4)$

where $p$ is the maximum number of lagged observations included in the model (the model order), the matrix $A$ contains the coefficients of the model (i.e., the contributions of each lagged observation to the predicted values of $\mathrm{Y}_{(\mathrm{t})}, \mathrm{FDI}_{\mathrm{tpri}}, \mathrm{FDI}_{\mathrm{tsec}}$ and $\mathrm{FDI}_{\mathrm{tter}}, E_{1}, E_{2}, E_{3}$, and $E_{4}$ are residuals (prediction errors) for each time series. If the variance of $E_{1}$, or $\left(E_{2}, E_{3}\right.$ and $\left.E_{4}\right)$ is reduced by the inclusion of the $\mathrm{Y}_{(\mathrm{t}) \text {, }}$ or $\left[\mathrm{FDI}_{\mathrm{tpri}}, \mathrm{FDI}_{\mathrm{tsec}}\right.$, $\left.\mathrm{FDI}_{\mathrm{tter}}\right]$ terms in the first (or second through fourth) equation, then it is said that $\mathrm{Y}_{(\mathrm{t})}$ or $\left[\mathrm{FDI}_{\mathrm{tpri}}, \mathrm{FDI}_{\mathrm{tsec}}, \mathrm{FDI}_{\mathrm{tter}}\right]$ Granger-(G)-causes $\mathrm{Y}_{(\mathrm{t})}$ or $\left[\mathrm{FDI}_{\mathrm{tpri}}, \mathrm{FDI}_{\mathrm{tsec}}, \mathrm{FDI}_{\mathrm{tter}}\right]$. Other words, $Y_{(\mathrm{t})}$ G-causes $\mathrm{FDI}_{\mathrm{tpri}}, \mathrm{FDI}_{\mathrm{tsec}}, \mathrm{FDI}_{\mathrm{tter}}$ if the coefficients in $A_{12}$ are jointly significantly different from zero. This can be tested by performing an F-test of the null hypothesis that $A_{12}=0$, given assumptions of covariance stationarity on $\mathrm{Y}_{(\mathrm{t})}, \mathrm{FDI}_{\mathrm{tpri}}, \mathrm{FDI}_{\mathrm{tsec}}$, and $\mathrm{FDI}_{\mathrm{tter}}$. The magnitude of a G-causality interaction can be estimated by the logarithm of the corresponding F-statistic (Geweke 1982). Note that model selection criteria, such as the Bayesian Information Criterion (BIC, (Schwartz 1978)) or the Akaike Information Criterion (AIC, (Akaike 1974)), can be used to determine the appropriate model order $p$. (Seth 2007).

\subsection{Description of Data and Source}

The data used in this work are yearly actual utilized FDI in 21 sectors of China's economy and the data are then group into three industries namely Primary, secondary and tertiary industry according to the national industrial classification of china and all data are in tenths of millions US Dollars and the GDP is real Gross domestic product in US Dollar, data are annual time series data, the value are transformed to log forms.

4.1.

\section{Result and Discussion}

Table 4.1

\begin{tabular}{|l|l|l|l|l|}
\hline Variable & LFDI $_{\mathbf{t}}$ & LFDI $_{\text {tpri }}$ & LFDI $_{\text {tsec }}$ & LFDI $_{\text {tter }}$ \\
\hline KPSS & 0.153 & 0.153 & 0.125 & 0.145 \\
\hline Critical Value (*) & 0.216 & 0.216 & 0.216 & 0.216 \\
\hline Result & $\mathbf{I}(\mathbf{0})$ & $\mathbf{I}(\boldsymbol{0})$ & $\boldsymbol{I}(\boldsymbol{0})$ & $\boldsymbol{I}(\mathbf{0})$ \\
\hline
\end{tabular}

Table 4.1 shows the result of unit root test of all the variables used in this work. The Result implies that all the variable are stationary at level as the KPSS test is smaller than the critical value at $1 \%$, The overall conclusion is that we are dealing with a set of $\mathrm{I}(0)$ variables which, by definition, yields a long-run co-integrating vector. The estimated model is therefore suitable to perform our analysis on the medium-run Contribution of the exogenous variables to economic growth movements.

\subsection{Granger Causality Test}

Analyzing how the inflows of FDI would cause economic growth, we would like to know whether changes in FDI variable will have an impact on changes on the economic growth variable. The granger causality test assumes that the information relevant to the prediction of the respective variables is contained in the time series data on these variables. Since the variable as shown in the unit root test are stable at level, we would proceed with the analysis using the variables at level. 
Effect Of Foreign Direct Investment On China Economic Growth: A Granger Causality Approach.

Table 4.2. Granger causality test result

\begin{tabular}{|l|l|l|l|l|}
\hline Null Hypothesis: & Obs & F-Statistics & Prob & Decision \\
\hline LnPri does not granger cause LnRGDP & 14 & 0.35967 & 0.5608 & Do not reject \\
LnRGDP does not granger cause LnPri & & 3.98328 & 0.0713 & Do not reject \\
\hline LnSec does not granger cause LnRGDP & 14 & 0.14958 & 0.0063 & Reject \\
LnRGDP does not granger cause LnSec & & 7.64192 & 0.0184 & Reject \\
\hline LnTer does not granger cause LnRGDP & 14 & 1.21115 & 0.2946 & Do not reject \\
LnRGDP does not granger cause LnTer & & 5.50915 & 0.0387 & Reject \\
\hline
\end{tabular}

(Summary result of equation 1-4)

Table 4.2, shows that using the Granger causality test, from the first equation there is no casual effect running there is no causal effect running both ways between the FDI in primary industry to Real GDP growth and from Real GDP to FDI in primary industry of the economy, implying that neither causality is running form FDI in primary industry to Real GDP (LnPri $\rightarrow$ LnRGDP or LnRGDP $\rightarrow$ LnPri) this means that FDI in Primary Industry does not cause RGDP growth nor RGDP cause FDI in primary industry. This result is consistent with Lipsy, (2002) and UNCTAD (2001).

The second equation shows that causality is running bi-directionally from both FDI in secondary industry to Real GDP and from RGDP to FDI in primary industry of the economy (LnSec $\leftrightarrow$ RGDP), implying that FDI in secondary industry cause growth of RGDP and also RGDP cause increase in FDI in secondary industry of the economy, which means FDI in secondary lead to economic growth and as the economic growth FDI utilization in secondary industry increase too. Our result agreed with Laura, (2003) and Nadia (2006).

And in the third equation causality is running from RGDP to Tertiary industry of the economy (LnRGDP $\rightarrow$ LnTER) it then means that RGDP cause FDI in tertiary industry which implies that FDI flows into tertiary industry as a result of growth of the economy rather than the other way run as asserted by many people. This finding is in tune with the findings of Kashava (2008) and Jiang and Masaru (2010).

\section{Conclusion}

The study focuses on causal effect of FDI on economic growth of China, granger causality test and KPSS stationarity test was employed in the empirical analysis. Prior to the granger causality test a Stationarity test was carried out using Kwiatkowski-Phillips-Schmidt-Shin (KPSS), the variables was found to be stationary at level.

The Pairwise Granger Causality was carried out to determine the direction of Causality among the variables, at least in the short run. The Granger Causality test indicates no relationship exist between FDI in the primary industry and economic growth, implying that FDI in primary industry does not granger cause economic growth and economic growth does not granger cause FDI in the primary industry of the economy.

Furthermore, in the secondary industry there exist a bi-directional relationship between FDI in secondary sector and economic growth, imply that FDI in the secondary industry granger cause economic growth and as the economic growth FDI in secondary industry also increase too. And in the Tertiary industry there is a unilateral relationship from economic growth to FDI in this industry, implying that economic growth cause FDI in tertiary industry of the economy.

\subsection{Policy Recommendation}

Based on our findings we recommend as follows; (1) Countries intending to benefit from FDI should carry out necessary and sufficient research before rolling out the policy and do so strategically as no all industry has casual effect on economic growth, (2) The authority of host nation should divide foreign investment market to encouraged, restricted and prohibited industries. (3) Countries should provide necessary incentive to FDI flowing to secondary and tertiary industry of the economy where necessary.

\section{References}

[1]. Agrawal, R., and Shahani, R.(2005). Foreign Investment in India: Issues and Implications for Globalisation. In: C. Tisdell (ed.), Globalisation and World Economic Policies: Effects and Policy Responses of Nations and their Groupings. New Delhi (Serials Publ.): . 644-658.

[2]. Anil, S. (2007) Scholarpedia, 2(7):1667. http://www.scholarpedia. org/Article//User:Anil_Seth.

[3]. Chandana, C.\& Peter. N.( 2006) Economic Reforms, Foreign Direct Investment and its Economic Effects in India, The Kiel Institute for the World Economy Duesternbrooker Weg 120, 24105 Kiel Germany, Kiel Working Paper No. 1272.

[4]. Christopher, E. (2007) The FDI - employment link in a globalizing world: The case of Argentina, Brazil and Mexico, Employment Analysis Unit, Employment Strategy Department, Employment Strategy Papers.

[5]. Enderwick, P. (2005). Attracting "Desirable" FDI: Theory and Evidence. Transnational corporations 14 (2): $93-119$.

[6]. Edward, M., G. and Erika W. (2001), foreign direct investment in china: Effects on Growth and Economic Performance, Institute for International Economics: To appear in Achieving High Growth: Experience of Transitional Economies in East Asia, Peter Drysdale, editor, Oxford University Press.

[7]. Fung, K.C., Hitomi, I., and Sarah, T. (2002). Foreign Direct Investment in China: Policy, Trend and Impact, Paper prepared for an international conference on China's Economy in the $21^{\text {st }}$ Century.

[8]. Granger, C.W.J. (1988). Some Recent Developments in a Concept of Causality. Journal of Econometrics 39, $199-211$. 
[9]. Granger, C.W.J., and Weiss, A, A. (1983). Time Series Analysis of Error Correction Models. In: S. Karlin, T. Amemiya and L.A. Goodman (eds.), Studies in Econometrics: Time Series and Multivariate Statistics. New York (Academic Press): 255-278.

[10]. Huang, S. (2003) Foreign Direct Investment and Regional Growth in China, Economics and Finance, and CEDI, Brunel University.

[11]. James, L. and Kam, K. Tang (2006) China's FDI-income growth nexus, The $17^{\text {th }}$ Annual Conference of the Association for Chinese Economic Studies (Australia) to be at Victoria University, Melboume July 20-21, JEL Classification F21, F52.

[12]. Jiang, J. and Masaru, L. (2010) How does FDI affect the regional Economic growth in China? Evidence from sub-regions and industries of the Jiangxi Province, P.R. China, IDEC, Hiroshima University Discussion Paper.

[13]. John, W., and Xian, X. (2006). China's FDI and Non-FDI Economies and the Sustainability of Future High Chinese Growth, National Bureau of Economic Research Working Paper No. 12249 JEL No. F43, O40.

[14]. Keshava S. R. ( 2008) The effect of FDI on India and Chinese Economy; A comparative analysis, Faculty, Post Graduate Department of Economics, Bangalore University, Bangalore-56005.

[15]. Lo W., L. (2005) Foreign Investment in Guangdong: Effects on Economic Growth and Regional Distribution Determinants, Hong Kong Baptist University.

[16]. Laura A. (2003). Foreign Direct Investment and Growth: Does the Sector Matter, Harvard Business School, 12249.

[17]. Lipsey, R. E. (2002). Home and Host Country Effects of FDI. National Bureau for Economic Research,Working Paper No. 92939.

[18]. Nadia, D. (2006) Does the worldwide shift of FDI from manufacturing to services accelerate economic growth- a GMM estimation study. The Graduate Center, CUNY JEL. F2, F21, F43.

[19]. Nicole, M. and Sandra, P. (2006) FDI impact on growth: spatial evidence from China, JEL Codes: E1, O1, O5, R1.

[20]. Omoke P. C. and Ugwuanyi C. U. (2010) Export, Domestic Demand and Economic Growth in Nigeria: Granger Causality Analysis, European Journal of Social Sciences - Vol.13,No. 2. 211-218

[21]. Samuel A. (2009) Can foreign direct investment (FDI) help to promote growth in Africa?, Ghana Institute of Management and Public Administration P. O. Box AH 50, Achimota, Ghana.

[22]. Tam B., Vu B. G., and Ilan, N. (2006). Is foreign direct investment good for growth? evidence from sectoral analysis of china and Vietnam.

[23]. Whalley, J., and Xian, X. (2006). China's FDI and Non-FDI Economies and the Sustainbility of Future High Chinese Growth. National Bureau Economics Research Working Paper 12249.

[24]. Wen, M. (2003). FDI, Regional Geographical and Market Conditions, and Regional Development: A Panel Study on China. Division of Economics, RSPAS, ANU, 15.

[25]. Wanda, T. and Harm, Z. (2003). Foreign Direct Investment In China: Some Lessons for Other International Monetary fund Discussion Paper.

[26]. Zhang, K. (2001). How Does FDI Affect Economic Growth in China? Economics of Transition. Vol 3(1) 21-25

\section{Appendixes}

\section{Appendix 1, Unit root test for log of real GDP}

Null Hypothesis: LGDP is stationary

Exogenous: Constant, Linear Trend

Bandwidth: 2 (Newey-West automatic) using Bartlett kernel

\begin{tabular}{llc}
\hline \hline & & \\
\hline \hline Kwiatkowski-Phillips-Schmidt-Shin test statistic & & 0.122315 \\
\hline Asymptotic critical values*: & $\begin{array}{c}\text { 1\% level } \\
5 \% \text { level }\end{array}$ & 0.216000 \\
& $10 \%$ level & 0.146000 \\
& 0.119000 \\
\hline \hline *Kwiatkowski-Phillips-Schmidt-Shin (1992, Table 1) & \\
\hline \hline Residual variance (no correction) & 0.173573 \\
HAC corrected variance (Bartlett kernel) & 0.152324 \\
\hline \hline
\end{tabular}

KPSS Test Equation

Dependent Variable: LGDP

Method: Least Squares

Date: 13/10/13 Time: 07:46

Sample: 19952009

Included observations: 15

\begin{tabular}{ccccc}
\hline \hline Variable & Coefficient & Std. Error & t-Statistic & Prob. \\
\hline \hline C & 10.07364 & 0.220001 & 45.78913 & 0.0000 \\
@TREND(1995) & 0.219407 & 0.026745 & 8.203780 & 0.0000 \\
& & & \\
\hline \hline
\end{tabular}


R-squared

Adjusted R-squared

S.E. of regression

Sum squared resid

Log likelihood

F-statistic

Prob(F-statistic)
0.838111 Mean dependent var

0.825658 S.D. dependent var

0.447523 Akaike info criterion

2.603602 Schwarz criterion

-8.150419 Hannan-Quinn criter.

67.30201 Durbin-Watson stat

0.000002
11.60949

1.071802

1.353389

1.447796

1.352384

1.387744

\section{Appendix 2, Unit root test for log FDI in Primary Industry}

Null Hypothesis: LPRI is stationary

Exogenous: Constant, Linear Trend

Bandwidth: 0 (Newey-West automatic) using Bartlett kernel

LM-Stat.

\begin{tabular}{lcc}
\hline \hline Kwiatkowski-Phillips-Schmidt-Shin test statistic & 0.152967 \\
\hline Asymptotic critical values*: & $1 \%$ level & 0.216000 \\
& $5 \%$ level & 0.146000 \\
$10 \%$ level & 0.119000 \\
\hline \hline
\end{tabular}

*Kwiatkowski-Phillips-Schmidt-Shin (1992, Table 1)

\begin{tabular}{ll}
\hline \hline Residual variance (no correction) & 0.088174 \\
HAC corrected variance (Bartlett kernel) & 0.088174 \\
\hline
\end{tabular}

KPSS Test Equation

Dependent Variable: LPRI

Method: Least Squares

Date: 13/10/13 Time: 08:02

Sample: 19952009

Included observations: 15

\begin{tabular}{lrlrl}
\hline \hline \multicolumn{1}{c}{ Variable } & Coefficient & \multicolumn{1}{c}{ Std. Error } & t-Statistic & Prob. \\
\hline \multicolumn{1}{c}{ C } & 11.44083 & 0.156803 & 72.96329 & 0.0000 \\
\multicolumn{1}{c}{ @TREND(1995) } & 0.000592 & 0.019062 & 0.031034 & 0.9757 \\
\hline \hline R-squared & 0.000074 & Mean dependent var & 11.44497 \\
Adjusted R-squared & -0.076843 & S.D. dependent var & 0.307375 \\
S.E. of regression & 0.318966 & Akaike info criterion & 0.676102 \\
Sum squared resid & 1.322613 & Schwarz criterion & 0.770509 \\
Log likelihood & -3.070769 & Hannan-Quinn criter. & 0.675097 \\
F-statistic & 0.000963 & Durbin-Watson stat & 0.758020 \\
Prob(F-statistic) & 0.975714 & & \\
\hline \hline
\end{tabular}

\section{Appendix 3, Unit root test for log FDI in Secondary Industry}

Null Hypothesis: LSEC is stationary

Exogenous: Constant, Linear Trend

Bandwidth: 2 (Newey-West automatic) using Bartlett kernel

\begin{tabular}{llc}
\hline \hline & & LM-Stat. \\
\hline \hline Kwiatkowski-Phillips-Schmidt-Shin test statistic & & 0.124840 \\
\hline Asymptotic critical values*: & 1\% level & 0.216000 \\
& $5 \%$ level & 0.146000
\end{tabular}


*Kwiatkowski-Phillips-Schmidt-Shin (1992, Table 1)

\begin{tabular}{ll}
\hline \hline Residual variance (no correction) & 0.050883 \\
HAC corrected variance (Bartlett kernel) & 0.094105 \\
\hline \hline
\end{tabular}

KPSS Test Equation

Dependent Variable: LSEC

Method: Least Squares

Date: 13/10/13 Time: 08:04

Sample: 19952009

Included observations: 15

\begin{tabular}{lcccc}
\hline \hline \multicolumn{1}{c}{ Variable } & Coefficient & Std. Error & t-Statistic & Prob. \\
\hline \multicolumn{1}{c}{ C } & 15.18494 & 0.119116 & 127.4805 & 0.0000 \\
\multicolumn{1}{c}{ @TREND(1995) } & 0.009073 & 0.014480 & 0.626566 & 0.5418 \\
\hline \hline R-squared & 0.029314 & Mean dependent var & 15.24845 \\
Adjusted R-squared & -0.045355 & S.D. dependent var & 0.236990 \\
S.E. of regression & 0.242304 & Akaike info criterion & 0.126321 \\
Sum squared resid & 0.763248 & Schwarz criterion & 0.220728 \\
Log likelihood & 1.052592 & Hannan-Quinn criter. & 0.125316 \\
F-statistic & 0.392585 & Durbin-Watson stat & 0.523614 \\
Prob(F-statistic) & 0.541791 & & \\
\hline \hline
\end{tabular}

\section{Appendix 4, Unit root test for log FDI in tertiary Industry}

Null Hypothesis: LTER is stationary

Exogenous: Constant, Linear Trend

Bandwidth: 1 (Newey-West automatic) using Bartlett kernel

\begin{tabular}{lcc}
\hline \hline & & LM-Stat. \\
\hline \hline Kwiatkowski-Phillips-Schmidt-Shin test statistic & & 0.144744 \\
\hline Asymptotic critical values*: & $1 \%$ level & 0.216000 \\
& $5 \%$ level & 0.146000 \\
& $10 \%$ level & 0.119000 \\
\hline \hline
\end{tabular}

*Kwiatkowski-Phillips-Schmidt-Shin (1992, Table 1)

\begin{tabular}{lc}
\hline \hline Residual variance (no correction) & 0.303335 \\
HAC corrected variance (Bartlett kernel) & 0.345952 \\
\hline \hline
\end{tabular}

KPSS Test Equation

Dependent Variable: LTER

Method: Least Squares

Date: 13/10/13 Time: 08:06

Sample: 19952009

Included observations: 15

\begin{tabular}{ccccc}
\hline \hline Variable & Coefficient & Std. Error & t-Statistic & Prob. \\
\hline \hline C & 13.74015 & 0.290833 & 47.24411 & 0.0000 \\
\hline
\end{tabular}


Effect Of Foreign Direct Investment On China Economic Growth: A Granger Causality Approach.

\begin{tabular}{lrlll}
\multicolumn{1}{r}{$@$ @TREND(1995) } & 0.069792 & \multicolumn{1}{c}{0.035355} & 1.973999 & 0.0700 \\
\hline \hline R-squared & 0.230618 & Mean dependent var & 14.22869 \\
Adjusted R-squared & 0.171434 & S.D. dependent var & 0.649938 \\
S.E. of regression & 0.591610 & Akaike info criterion & 1.911627 \\
Sum squared resid & 4.550030 & Schwarz criterion & 2.006034 \\
Log likelihood & -12.33721 & Hannan-Quinn criter. & 1.910622 \\
F-statistic & 3.896673 & Durbin-Watson stat & 1.441877 \\
Prob(F-statistic) & 0.070020 & & \\
\hline \hline
\end{tabular}

Appendix 5, Granger Causality Test

Pairwise Granger Causality Tests

Date: 13/10/13 Time: 04:10

Sample: 19952009

Lags: 1

\begin{tabular}{lccc}
\hline \hline Null Hypothesis: & Obs & F-Statistic & Prob. \\
\hline \hline LNPRI does not Granger Cause LNRGDP & \multirow{2}{*}{14} & 0.35967 & 0.5608 \\
LNRGDP does not Granger Cause LNPRI & & 3.98328 & 0.0713 \\
\hline \hline LNSEC does not Granger Cause LNRGDP & \multirow{2}{*}{14} & 0.14956 & 0.0063 \\
LNRGDP does not Granger Cause LNSEC & & 7.64192 & 0.0184 \\
\hline \hline LNTER does not Granger Cause LNRGDP & \multirow{2}{*}{14} & 1.21115 & 0.2946 \\
LNRGDP does not Granger Cause LNTER & & 5.50915 & 0.0387 \\
\hline \hline LNSEC does not Granger Cause LNPRI & \multirow{2}{*}{14} & 0.12724 & 0.7281 \\
LNPRI does not Granger Cause LNSEC & & 0.28202 & 0.6059 \\
\hline \hline LNTER does not Granger Cause LNPRI & \multirow{2}{*}{14} & 9.34076 & 0.0109 \\
LNPRI does not Granger Cause LNTER & & 0.26248 & 0.6186 \\
\hline \hline LNTER does not Granger Cause LNSEC & 14 & 3.86000 & 0.0752 \\
LNSEC does not Granger Cause LNTER & & 0.10105 & 0.7565 \\
\hline \hline
\end{tabular}

